\title{
Research on Applied Undergraduate Education Reform Based on T-shaped Talent Training Mode
}

\author{
Z.J.WANG \\ Chongqing University of Science \& Technology, Chongqing, China \\ L.M.WU \\ Chongqing Technology \& Business Institute, Chongqing, China
}

\begin{abstract}
Construction of application technique universities is the development thought of universities under the new situation. It is also the problem and challenge average undergraduate universities encounter during their process of transforming into application technique universities to do talent training reform. Economic development of modern society needs compound talents. However, students can never adapt to actual demands just depending on single expertise. Horizontally, students need to acquire encyclopedic knowledge. Longitudinally, their expertise is needed to keep certain precision. Based on this, this paper discusses about contents, targets, teaching problems, solutions and expectations of T-shaped talent training mode on the basis of talent training mode of application-oriented undergraduate universities. It is to provide significant references for the research on talent training mode of average undergraduate universities for their transformation into application technique universities.
\end{abstract}

KEYWORD: talent training mode; T-shaped talents; applied undergraduate

\section{REALISTIC IMPORTANCE OF RESEARCH}

Premier Li Keqiang chaired a State Council executive meeting on February 26, deploying accelerated development of modern vocational education, deliberating and approving the Personnel Management Regulations of Public Institutions (draft). The meeting pointed out that guide a group of average undergraduate universities to transform into application technique universities [1]. Some educators think that this measure marks the unconscious coming of Chinese application technique universities times. Facing the proposition of average undergraduate universities transforming into application technique ones, some universities take advantages of this opportunity to plan new reform measures. While some universities hesitate and wander, intending to observe for a period of time. Many presidents of average undergraduate universities keep discussing the same topic in all kinds of seminars, symposiums and even in private. This topic is how to meet the arrival of application technique universities times [2].

In the future, the transformed local undergraduate universities would become the In the future, the transformed local undergraduate universities would become the application technique ones which hold the important position of training the largest proportion of highly educated talents. Application technique universities should focus on exploring effective paths which are suitable for our applied undergraduate universities to widely use in order to train entrepreneurial talents. Economic development of modern society needs compound talents. However, students can never adapt to actual demands just depending on single expertise. Horizontally, students need to acquire encyclopedic knowledge. Longitudinally, their expertise is needed to keep certain precision [3]. In addition, modern society emphasizes more practicability, adaptability and comprehensiveness on talents. Therefore students have to not only acquire book knowledge but also train their practical capability of solving problems in practice [3]. This T-shaped talent training project improves the traditional teaching method. Its main feature is that it is employment oriented and features practice. It trains applied talents who directly face enterprises, keeping high social relevance and practical significance.

\section{MAIN CONTENTS OF RESEARCH}

Using reformation of T-shaped talent training mode as entry point and aiming to train innovation and entrepreneurial capacity of students, we should establish curriculum system of practicing innovation education, improve knowledge structure of students 
and enhance their innovation and practice ability. Concrete contents include the following six aspects.

Highlight professional features of universities and promote core competence of professions. The transverse line and vertical line on $\mathrm{T}$ talent training mode are closely related which support each other. The transverse line on top of $\mathrm{T}$ stands for basis and premise of students' development. The vertical line means promotion of their professional ability.

Construct practice platform hardware. Consolidate and regulate the existing off-campus production and practice bases thus developing new ones for students. Improve the construction of training rooms and their operating management. Increase the openness of laboratories.

Build the operation mechanism of practice platform. Construct interaction and cooperation among production and practice bases, laboratories and teachers' offices. Facilitate collaboration between universities and enterprises. Coordinate practice segments of students inside and outside school and actually enhance their application ability using practice bases as a bridge.

Research teaching materials in the way of reverse practice. Go deep into enterprises to do post investigation, identify their real talent requirements, extract knowledge points, skill points and key work processes and finally do theory transition, lesson plans formation and teaching materials research.

Plan to do innovative training on university students. Educational and teaching reform is an important component of $\mathrm{T}$-shaped talent training mode. Universities give innovation projects to teachers and students, provide them with certain expenditure and supply opportunities of innovation training to students thus leading them to quickly enter each professional innovation field, making them contact academic foreland and having them understand developing dynamic of subjects.

Plan to lead university students to become selfemployed. Organize activities of entrepreneurial education and entrepreneurial practice. Systematically educate them about entrepreneurial consciousness, entrepreneurial knowledge, entrepreneurial skills and especially entrepreneurial spirit. Further stimulate their entrepreneurial enthusiasm and change their employment concepts.

\section{RESEARCH TARGETS}

According to the research contents determined by Tshaped talent training mode which would be used in applied undergraduate education, we set the following research targets.

Through constructing practice platform, we should train and establish a team of teachers who are adept and good at combining practical education with classroom education.
Through utilizing effective operating mechanism of practice platform, we must actually improve students' application and innovation abilities and increase the number and quality of them attending scientific innovation activities, mathematical modeling competitions and structural design contests.

Train senior-applied specialized talents. The graduate should not only have basic professional theoretical knowledge but also keep relevant professional technical capacity which may help them do technical guidance and practical management on the operation site. Their employment would be the first line of production, service and management.

Through let these students attend innovation training plan, we aim to strengthen their innovation sense and practical ability, improve collaborative communication, develop their teamwork spirit and increase their comprehensive quality.

By utilizing self-employed plan, we are intended to strengthen entrepreneurial education, promote status of entrepreneurial education to make it be equal to traditional employment education and academic education, expand students' employment, increase their employment skills and improve their employment rate.

\section{PROBLEMS NEEDING SOLVING}

The following problems needs solving during the implementation process of $\mathrm{T}$-shaped talent training mode utilized in applied undergraduate education.

Three different types of practice platform including off-campus practice, in-campus training and teachers hosting research projects should cooperate and mutually promote.

Select research units and university-enterprise cooperation units.

Develop innovation consciousness and experience innovation process through attending innovation practice.

Break boundaries of theoretical course, experimental course and training course thus carrying out integration teaching covering theory, experiment and training.

\section{APPROACHES TAKEN}

In terms of problems needing solving during the implementation process of $\mathrm{T}$-shaped talent training mode utilized in applied undergraduate education, we find out the following approaches to make it.

Under the guidance of teachers, we should effectively stimulate students' subjective initiative and innovation ability of acquiring knowledge proceeding from actual situation. Inspire them to attend competitions using knowledge to solve 
practical problems. Implement the idea of keeping students-oriented, combining in-class teaching with out-class activities and uniting teaching with research.

Strengthen the construction of teachers' training rooms. Construct training rooms according to teachers' research directions and strong points. Propose specific management and assessment targets. Teachers may be led to absorb students to enter training rooms who would be included in the assessment. Promote the combination of training room construction and enterprise requirements.

Maintain the principle of strengthening practice and emphasizing innovation. Carefully design comprehensive and designing experiments. Improve course system of teaching content reform and practice including practice and training, diploma project and scientific and technological activities in and out of class. Establish mechanism of innovation spirit training.

Design perfect operation mechanism of multidimensional practice platform and guarantee the continuous improvement and development of them. Divide practice process of students into three sections which are understanding practice, generating practice and graduation practice. Each practice stage of the same profession is guided by 2 or 3 teachers. Students would choose teachers with different research directions to guide their production practice according to their own interests and then enter different practice bases.

Keep the principle of emphasizing students' individuality development. Based on the thought of training talents for serving economic construction and taking social evaluation as the final standard of schooling level, we should satisfy diversified demands on talents of society, increase the proportion of elective courses, offer flexible courses and train students' individuality development.

Create the plan of entrepreneurship training for students. Establish course system of innovation and entrepreneurship education, improve students' knowledge structure and promote their innovation and practice abilities.

\section{ANALYSES ON DESIRED EFFECTS}

If T-shaped talent training mode would be effectively implemented in applied undergraduate education, the following desired effects may be achieved.

Practice platforms of university students are expanded. Three sections of practice including understanding practice, generating practice and graduation practice get gradually carried out.

Practice innovation capability of university students acquires remarkable promotion. Their innovation consciousness and practice ability are also improved. Cooperation communication of them is enhanced. Teamwork spirit is cultivated. Comprehensive quality is increased.

Practice teaching mode would be established in which in-campus professional teachers cooperate with industrial engineers to guide students' production practice.

Exactly improve application and innovation capabilities of students. Increase the number and quality of students attending scientific and technological innovation activities.

Train students to possess entrepreneurial consciousness, entrepreneurial knowledge and entrepreneurial skills. Improve their employment ability. Enhance their employment rate.

\section{CONCLUSIONS}

Transformation development of average undergraduate universities is global, complicated and long-term reformation in which reform of talent training mode is the essential step for their transformation into application technique universities [1]. T-shaped talent training plays a positive role in improving core competence of students' employment and promoting the transformation of average undergraduate universities thus guaranteeing the central status of teaching work. Its target is to train well-qualified talents to cater for national and local development and emphasis is to enhance their competitive ability. Insisting on developing and innovating and keeping people-oriented principle, it establishes distinctive talent training mode thus effectively improving the quality of higher education.

\section{ACKNOWLEDGEMENTS}

This work was supported by the education reform project "Research and Practice on Construction of Architecture Practice Teaching Base of Higher Vocational College" (GZJG1312820) of Chongqing Technology \& Business Institute.

\section{REFERENCES}

[1] F.CHEN. Thinking of several problems about part of the ordinary undergraduate colleges and universities development in transition. China Highe Education, 2012 (12): 16-20.

[2] S.X.DONG. Guide a number of common colleges and universities is an important measure of quickening the transformation, the comprehensive reform of Education University of applied technology era how to meet. Chinese Teaching, 2014, 4, 26(001).

[3] "T talents" and "X talents". Xian Dai Yuan Ju Li Jiao Yu, 1991, S1. 
[4] J.X.TAN On the construction of training mode of T-type in higher vocational and technological college. Journal of Higher Education. 2005, 10(26): 68-72.
[5] A.P.WU, H.XING. Exploration and Practice on Training Mode of Applied Innovative Undergraduates. Journal of Changchun University, 2011, 21(12):131-134. 